\title{
Infection with the Avian-Battey Group of Mycobacteria in England and Wales
}

\author{
W. B. SCHAEFER,* M.D. ; K. J. BIRN, † DR.MED.VET. ; P. A. JENKINS, $\ddagger$ PH.D. \\ J. MARKS, $\ddagger$ M.D., F.R.C.P., F.C.PATH.
}

$S^{\text {u }}$ ummary : Of 109 cases in England and Wales in which mycobacteria of the avian-Battey group were isolated from man 89 were considered genuine infections (including 32 with Mycobacterium avium) and six were doubtful. Almost half the significant cases were lung infections in men in dusty occupations, mostly coal miners with pneumoconiosis, and just over a quarter were nonpulmonary, mostly cervical adenitis in children. The prognosis in lung infections was serious, especially in the presence of pneumoconiosis.

\section{Introduction}

As tuberculosis declines, infections with other mycobacteria appear to be on the increase. The most important of these "opportunist" mycobacteria in Britain, Mycobacterium kansasii, is now well known, but the avian-Battey group, which ranks second, has attracted less attention. We now present the clinical and epidemiological aspects of a series assembled at the Tuberculosis Reference Laboratory, Cardiff, from sources in England and Wales.

\section{Subject Material}

Most of the opportunist mycobacteria isolated in Wales since 1952 have been collected at the Reference Laboratory, and its records of avian-Battey infection for this area are therefore fairly comprehensive. Strains have been submitted from England since 1960, but mainly since 1963 . Their collection has not been subject to any known bias except that London is thought to be underrepresented because of local arrangements for the examination of mycobacteria. Some of the English strains were sent for identification, some for sensitivity tests, and a smaller number were met in surveys of various kinds. Most of the cattle and bird strains were isolated at Weybridge. Three of the latter came from Wales, the rest and the former came from various sources in England. The pig strains were widely distributed over England and Wales.

\section{Classification}

The opportunist mycobacteria can be divided into aerophiles and microaerophiles. Subtraction from the microaerophiles of $M$. xenopei and the brightly pigmented bacteria related to $M$. scrofulaceum leaves the avian-Battey group, which consists of $M$. avium and organisms with varying degrees of similarity to it. Among the latter, entities are being defined by current work. Specific agglutination is helpful in this respect (Schaefer, 1965), having established two $M$. avium serotypes and a number of others, here called Battey after the sanatorium where they first attracted attention. The criteria of classification used for the present series of strains were those described previously

* National Jewish Hospital, Denver, Colorado.

† Central Veterinary Laboratory, Weybridge.

† Central Veterinary Laboratory, Weybridge.
(Birn et al., 1967). However, to simplify presentation the groups are here reduced to four: (1) M. avium, (2) Battey group of non-avian serotypes, (3) provisional species 1 and 2, and (4) strains not yet classifiable.

Since our previous study a third type of $M$. avium has been recognized, the bacteriological details of which will be given elsewhere.

The present series includes 10 cases previously published as $M$. avium infections (Marks and Birn, 1963). They are Cases $4,10,11,13,15,16,25,28,44$, and 52 (see Tables II and III). The latter two strains are now reclassified as Battey serotypes Davis and VI respectively ; in the first report it was assumed that a lethal effect on fowls in low dosage could be used to identify a mycobacterium as $M$. avium, but subsequent experience has shown that this degree of virulence is occasionally met in Battey strains (Birn et al., 1967).

\section{Epidemiology}

The avian-Battey mycobacteria isolated from man are compared in Table I with a series derived from birds, pigs, and cattle. The birds comprised 20 fowls, 7 pheasants, and 10 birds from seven other species; almost all the infections were visceral and widespread. All the pig lesions recorded were in lymph nodes, mainly submaxillary. Two cattle were slaughtered as tuberculin reactors but had no macroscopic lesions. The rest were killed for other reasons, specimens being submitted because tuberculosis was suspected at routine meat inspection. Most of the lesions found in cattle were in retropharyngeal lymph nodes, but some infections were more extensive ; one was generalized. The normal criteria of significance for man were (1) the presence of a lesion, (2) repeated isolation of the organism, and (3) exclusion of other causes. However, repeated isolation was sometimes waived when specimens were not repeatable-for example, with surgical specimens. Supporting evidence was obtained by microscopy or skin tests with $M$. avium antigen in some such cases. There were six doubtful cases which have been distinguished from the significant isolates in the Tables but not in the Figures.

\begin{tabular}{|c|c|c|c|c|c|c|}
\hline \multirow{3}{*}{ Source } & \multicolumn{5}{|c|}{ Number of Strains } & \multirow{3}{*}{$\begin{array}{c}\text { Not Yet } \\
\text { Classi- } \\
\text { fiable }\end{array}$} \\
\hline & \multicolumn{3}{|c|}{ M. avium } & \multirow{2}{*}{$\begin{array}{l}\text { Battey } \\
\text { Sero- } \\
\text { types } \\
\end{array}$} & \multirow{2}{*}{$\begin{array}{c}\text { Provisional } \\
\text { Species } \\
1 \text { and } 2 \\
\end{array}$} & \\
\hline & Type 1 & Type 2 & Type 3 & & & \\
\hline $\begin{array}{l}\text { Man: } \\
\text { Significant } \\
\text { Doubtful } \\
\text { Casual }\end{array}$ & $\begin{array}{l}9 \\
4 \\
1 \\
\end{array}$ & $\begin{array}{r}23 \\
1 \\
2\end{array}$ & $\begin{array}{l}0 \\
0 \\
0\end{array}$ & $\begin{array}{r}30 \\
1 \\
4 \\
\end{array}$ & $\begin{array}{r}11 \\
0 \\
1\end{array}$ & $\begin{array}{r}16 \\
0 \\
6 \\
\end{array}$ \\
\hline $\begin{array}{l}\text { Birds } \\
\text { Pigs } \\
\text { Cattle }\end{array}$ & $\begin{array}{l}5 \\
2 \\
0\end{array}$ & $\begin{array}{l}23 \\
17 \\
16\end{array}$ & $\begin{array}{l}9 \\
3 \\
0\end{array}$ & $\begin{array}{l}0 \\
2 \\
0\end{array}$ & $\begin{array}{l}0 \\
0 \\
0\end{array}$ & $\begin{array}{l}0 \\
1 \\
1\end{array}$ \\
\hline
\end{tabular}

All 37 of the avian-Battey strains from birds, 16 of the 17 cattle strains, and 22 of the 25 pig strains were $M$. avium but only 40 of the 109 human strains. The number of type 1 $M$. avium infections in man appears to have been inflated by 
a small epidemic (discussed below), but after allowance for this the analysis suggests that types 1 and 3 , especially the latter, are less infective for mammals than is type 2 . Our series includes no type 3 isolate from man, but a fatal infection in a child has been recorded in Scotland, though the type was not then known (Schonell et al., 1968). The virulence for fowls was tested on five strains of type 1,34 of type 2 , and seven of type 3 from animals and birds, a dose of $0.01 \mathrm{mg}$. intravenously being used. All were lethal. In contrast, 8 out of 11 strains of type 1 from man were avirulent for fowls, one was partially virulent, and two were virulent ; in one of the latter cases an isolate obtained five years later was avirulent. Of 24 type 2 strains from man, 22 were virulent, 1 partially so, and 1 avirulent. The type 3 strain from the Scottish child was slightly attenuated in virulence (Clark et al., 1968).

The distribution of $M$. avium infections in man known to us in England and Wales is recorded in Fig. 1 and infections by other members of the avian-Battey group in Fig. 2. As explained above, the records for Wales are the more complete and cover a longer period. $M$. avium infections have a rural emphasis in their distribution, allowing for their special association with pneumoconiosis, as might be expected from the organism's natural habitat in birds. A concentration of six cases of type 1 infection and one doubtful case in the Rhondda valley merits notice. An investigation showed no evidence of special exposure to infection from birds, but the patients were all pneumoconiotics living in a fairly confined area. It seems probable that this is an example of case-to-case infection in a group of especially susceptible people-that is, men with pneumoconiosis.

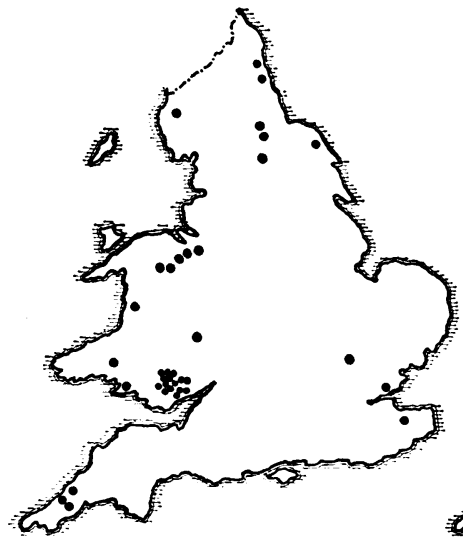

FIG. 1

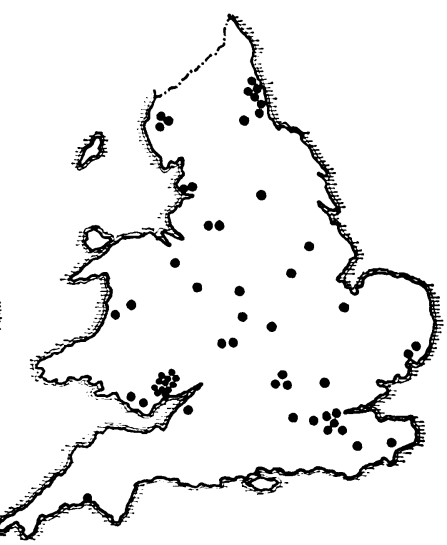

FIG. 2
FIG. 1.-Distribution of human infections with $M$. avium. FIG. 2.Distribution of human infections with non-avian members of the avianBattey group of mycobacteria.

Other members of the avian-Battey group are distributed more in accordance with population density when allowance is made for the underrepresentation of London explained above.

Casual isolates are recorded in Tables I and VI but not in the figures or elsewhere. On rare occasions laboratories may suffer an outbreak of false positives which can involve any cultivable species of mycobacterium, the cause being a breakdown in technique. No examples of this kind have been included in the present study. The non-significant isolation of a serotype VI strain from a child's urine is recorded in Table VI. This serotype was being currently isolated in the same laboratory (Case 33, Table III). Cross-contamination was made unlikely by a second culture from the child's urine. A possible explanation is that the organism lives normally in the area (Oxford) either as a commensal or freely. Opportunist mycobacteria may appear in the urine with disseminated infections, but we have not found their presence significant otherwise.

\section{Clinical Aspects}

M. avium.-Particulars of 32 cases of infections with $M$. avium are given in Table II. There were 26 pulmonary cases, mostly men with previous lung damage from dusty occupations. There were four cases of cervical adenitis in children and one of axillary adenitis in an adult. The case of wrist "ganglion" was diagnosed clinically as tuberculous but the histology was described as "rheumatoid." The patient reacted much more strongly to $M$. avium antigen than to tuberculin of equal protein content. The prognosis was poor in men who had worked in dusty occupations; about twothirds of them died in the period of observation and none is known to have become bacteriologically negative. When postmortem examinations were made, lesions simulating tuberculosis were found. The course of the adenitis cases was favourable, though excision was thought necessary in at least two cases.

TABLE II.-Infections with M. avium in England and Wales

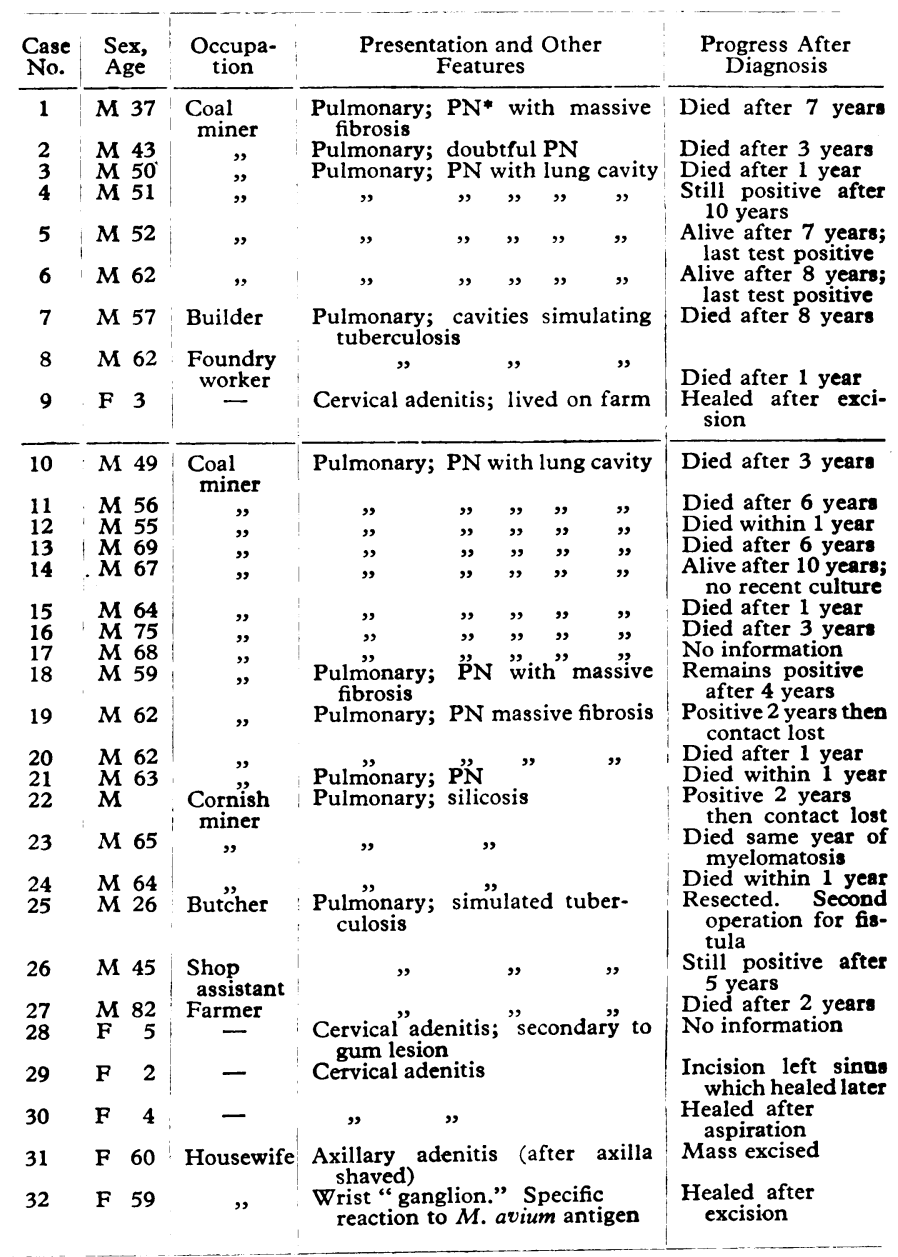
* PN = Pneumoconiosis.

The infecting organism was type $1 M$. avium in Cases $1-9$ and type 2 in the remainder.

Five cases of doubtful significance and three isolates classed as "casual" are recorded in Table VI. Designation as casual does not positively identify a strain as non-significant; inadequate investigation or follow-up may be responsible.

Battey Serotypes.-Infections with mycobacteria of Battey serotype are recorded in Table III. There were 17 pulmonary cases simulating tuberculosis, 12 of cervical adenitis, and one fatal disseminated infection. In comparison with the $M$. avium series, pneumoconiosis was less common as a predisposing factor and the mortality was lower. So far as was known all the cervical adenitis patients were children, most being under 
school age; information about them was meagre but the scarcity of repeat isolates suggests a benign course.

TABLE III.-Infections with Mycobacteria of Battey Serotypes in England and $W$ ales

\begin{tabular}{|c|c|c|c|c|c|}
\hline $\begin{array}{l}\text { Case } \\
\text { No. }\end{array}$ & $\begin{array}{l}\text { Sex, } \\
\text { Age }\end{array}$ & $\begin{array}{l}\text { Occupa- } \\
\text { tion }\end{array}$ & Serotype & $\begin{array}{l}\text { Presentation and Other } \\
\text { Features }\end{array}$ & $\begin{array}{l}\text { Progress After } \\
\text { Diagnosis }\end{array}$ \\
\hline 33 & M 53 & Mechanic & VI & $\begin{array}{l}\text { Disseminated infection } \\
\text { simulating miliary } \\
\text { tuberculosis }\end{array}$ & $\begin{array}{l}\text { Died within a } \\
\text { few months }\end{array}$ \\
\hline 34 & M 43 & Not & III & Pulmonary; tuberculosis & Positive for \\
\hline 35 & M 64 & Coal & IV & $\begin{array}{l}\text { Pulmonary; pneumoco- } \\
\text { niosis with lung cavity }\end{array}$ & Remains posi- \\
\hline 36 & M 48 & Welder & IV & Pulmonary; simulated & Resected \\
\hline 37 & M 64 & $\begin{array}{l}\text { Coal } \\
\text { miner }\end{array}$ & VII & $\begin{array}{l}\text { tuberculosis } \\
\text { Pulmonary; recent steroid } \\
\text { therapy }\end{array}$ & $\begin{array}{l}\text { Converted } \\
\text { after chemo- }\end{array}$ \\
\hline 38 & M 58 & Horti- & Yandle & Pulmonary; simulated & Still positive \\
\hline 39 & M 55 & Gardener & Yandle & 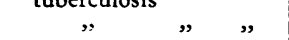 & Died after \\
\hline 40 & M 54 & $\begin{array}{l}\text { Coal } \\
\text { miner }\end{array}$ & Boone & $"$ & $\begin{array}{l}\text { Two lobecto- } \\
\text { mies. Died }\end{array}$ \\
\hline 41 & M 75 & Farmer & Boone & Pulmonary; tuberculosis & $\begin{array}{l}\text { arter } 4 \text { years } \\
\text { Died within a }\end{array}$ \\
\hline 42 & F 50 & Housewife & Altmann & Pulmonary; simulated & $\begin{array}{l}\text { year } \\
\text { Still positive } \\
\text { after } 2 \text { years }\end{array}$ \\
\hline 43 & M 60 & $\begin{array}{l}\text { Not } \\
\text { known }\end{array}$ & $\begin{array}{l}\text { Altmann } \\
\text { plus Boone }\end{array}$ & $\begin{array}{l}\text { Pulmonary; honeycomb } \\
\text { lung, alcoholic }\end{array}$ & $\begin{array}{l}\text { Still positive } \\
\text { after } 1 \text { year }\end{array}$ \\
\hline 44 & F 60 & Housewife & Davis & Pulmonary; achalasia of & Died after \\
\hline 45 & M 55 & Plastics & Davis & Pulmonary; simulated & No information \\
\hline 46 & M 63 & Chemicals & Watson & Pulmonary & Positive for \\
\hline 47 & M 61 & $\begin{array}{l}\text { Coal } \\
\text { miner }\end{array}$ & Watson & $\begin{array}{l}\text { Pulmonary; early pneu- } \\
\text { moconiosis, lung cavity }\end{array}$ & No information \\
\hline 48 & M 46 & Not $_{\text {known }}$ & $\begin{array}{c}\text { Howell- } \\
\text { Chance }\end{array}$ & Pulmonary; simulated & Resected \\
\hline 49 & M 57 & Printer & Lunning & $\begin{array}{l}\text { Pulmonary; activated by } \\
x \text {-ray therapy for sup- } \\
\text { posed carcinoma }\end{array}$ & $\begin{array}{l}\text { Diagnosis of } \\
\text { carcinoma } \\
\text { disproved at }\end{array}$ \\
\hline 50 & $\mathbf{M}$ & $\begin{array}{l}\text { Not } \\
\text { known }\end{array}$ & Wilson & $\begin{array}{l}\text { Pulmonary; simulated } \\
\text { tuberculosis }\end{array}$ & No information \\
\hline 51 & M 2 & - & IV & Cervical adenitis; bilateral & $\begin{array}{l}\text { Slow improve- } \\
\text { ment after }\end{array}$ \\
\hline 52 & & - & VI & Cervical adenitis & $\begin{array}{l}\text { Aspirated; no } \\
\text { further }\end{array}$ \\
\hline $\begin{array}{l}53 \\
54\end{array}$ & & - & & & $\begin{array}{l}\text { specimens } \\
\text { No information }\end{array}$ \\
\hline 55 & $\mathbf{M}$ & 二 & VII & & $"$ \\
\hline 56 & & & Yandle & $"$ & $\begin{array}{l}\text { Healed" after } \\
\text { surgical } \\
\text { drainage }\end{array}$ \\
\hline $\begin{array}{l}57 \\
58\end{array}$ & $\mathbf{M}$ & $\overline{-}$ & Yandle & " & No information \\
\hline & M & & & $"$ & $"$ \\
\hline & & & & ," & K"nown" to be a \\
\hline $\begin{array}{l}61 \\
62\end{array}$ & $\underset{\mathbf{F}}{\mathbf{F}}$ & - & $\begin{array}{l}\text { Darden } \\
\text { Arnold }\end{array}$ & ," & $\begin{array}{l}\text { No information } \\
,, \quad,\end{array}$ \\
\hline
\end{tabular}

Provisional Species 1 and 2.-Cases in this category are recorded in Table IV. One of six people infected with species 1 had silicosis and another was a coal miner. All five infected with species 2 had pneumoconiosis. Both types of infection appear to be serious. One man became negative four years after thoracoplasty but two patients died and the others for whom information is available have remained positive.

Table IV.-Infections with Mycobacteria of Provisional Species 1 and 2 in England and Wales

\begin{tabular}{|c|c|c|c|c|c|}
\hline $\begin{array}{l}\text { Case } \\
\text { No. }\end{array}$ & $\begin{array}{l}\text { Sex, } \\
\text { Age }\end{array}$ & $\begin{array}{c}\text { Occupa- } \\
\text { tion }\end{array}$ & Species & $\begin{array}{c}\text { Presentation and Other } \\
\text { Features }\end{array}$ & $\begin{array}{l}\text { Progress After } \\
\text { Diagnosis }\end{array}$ \\
\hline $\begin{array}{l}63 \\
64\end{array}$ & $\begin{array}{l}\text { M } 57 \\
\text { M } 64\end{array}$ & $\begin{array}{l}\text { Storeman } \\
\text { Driller }\end{array}$ & $\begin{array}{l}1 \\
1\end{array}$ & \multirow{5}{*}{$\begin{array}{l}\text { Pulmonary; lung cavity } \\
\text { Pulmonary; doubtful } \\
\text { silicosis; cavity } \\
\text { Pulmonary; cavity; } \\
\text { rheumatoid arthritis } \\
\text { Pulmonary; simulated } \\
\text { tuberculosis } \\
\text { Pulmonary; gastrectomy } \\
\text { Pulmonary; fibrosis at } \\
\text { apices }\end{array}$} & \multirow{5}{*}{$\begin{array}{l}\text { Died after } 3 \text { years } \\
\text { Still positive } \\
\text { after } 8 \text { years } \\
\text { Still positive } \\
\text { after } 4 \text { years } \\
\text { Positive } 4 \text { years. } \\
\text { Thoracoplasty } \\
\text { Recent case }\end{array}$} \\
\hline 65 & F 52 & Housewife & 1 & & \\
\hline 66 & M 63 & Salesman & 1 & & \\
\hline 67 & M 68 & Not known & 1 & & \\
\hline 68 & M 60 & Coal miner & 1 & & \\
\hline 69 & M 57 & Coal miner & 2 & $\begin{array}{l}\text { Pulmonary; pneumo- } \\
\text { coniosis }\end{array}$ & \multirow{3}{*}{$\begin{array}{l}\text { Positive } 7 \text { years. } \\
\text { Contact lost } \\
\text { Died after } 8 \text { years } \\
\text { Still positive } \\
\text { after } 6 \text { years } \\
\text { No information }\end{array}$} \\
\hline $\begin{array}{l}70 \\
71\end{array}$ & M 51 & $"$ & $\begin{array}{l}2 \\
2\end{array}$ & " $\quad$ " & \\
\hline $\begin{array}{l}72 \\
73\end{array}$ & $\underset{M}{M} 50$ & ", & $\begin{array}{l}2 \\
2\end{array}$ & ", & \\
\hline
\end{tabular}

Unclassified Members.-Infections with members of the avian-Battey group which cannot yet be classified are recorded in Table V. There were nine cases in which the organism gave a suitable suspension but no specific agglutination by any of the existing range of sera. Five of the patients had lung infections and four cervical adenitis. Variation in biochemical properties within the group suggest that it is not homogeneous and it presumably consists of members with new, rare serotypes. While one child (Case 80) was in hospital with cervical adenitis her budgerigar died. Its lung contained a lesion resembling tuberculosis and numerous acid-fast bacilli. Culture of the lung failed, but the organism was grown only with great difficulty from the child's excised glands. The two infections were probably connected but there is no clue as to which was primary, if either. Six strains could not be serotyped because of their rough nature. Five patients had lung infections and one patient had cervical adenitis. In one further pulmonary case the organism shared an antigen with $M$. avium but its other properties were inappropriate to the species.

TABLE V.-Infections in England and Wales with Avian-Battey Myco-

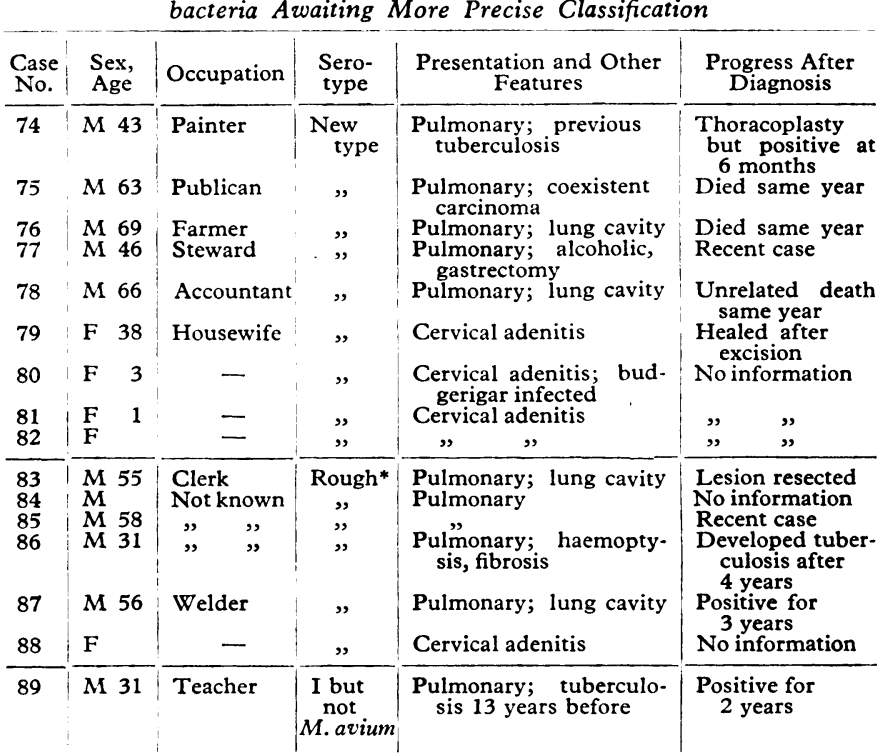

- Agglutination tests not possible because of failure to form or sustain a stable

Doubtful Cases.-Twenty cases are presented (Table VI) in which evidence was lacking to incriminate the mycobacteria isolated. Details are given which explain their division into 14 cases in which the organism is unlikely to have been significant and six which remained doubtful.

\section{Discussion}

The extent of the problem disclosed by the present series has been previously disguised by the sporadic nature of the infections concerned and is still imperfectly represented because many cases do not reach the Reference Laboratory. Infection of man by $M$. avium was considered very rare by Feldman (1938), and Griffith (1938) found no example in 7,800 cases of tuberculosis. If men with pneumoconiosis are excluded as having been perhaps poorly represented in his material, our experience of $M$. avium, being drawn from many more cultures, may not be incompatible with Griffith's. However, it is difficult to explain the frequency of other members of the avian-Battey group except by a real increase in prevalence, and if this is true it probably applies to $M$. avium also. Better technique has undoubtedly improved the recognition of opportunist infections in general, but in Wales their incidence has about doubled in the past 10 years, during which period the methods used have been reasonably uniform. 
The avian-Battey mycobacteria appear to have a low infectivity for man, as healthy contacts are rarely affected. If innate immunity to different species of mycobacteria has a common basis, the increase in opportunist infections is explicable by the growing proportion of highly susceptible persons in the community, spared by the recession of tuberculosis. Other predisposing factors such as damage to the lungs by industrial fumes or dust and conditions which favour aspiration pneumonia may be crucial in individual cases, but there is no evidence that they are becoming more prevalent. The influence of smoking awaits investigation, however.

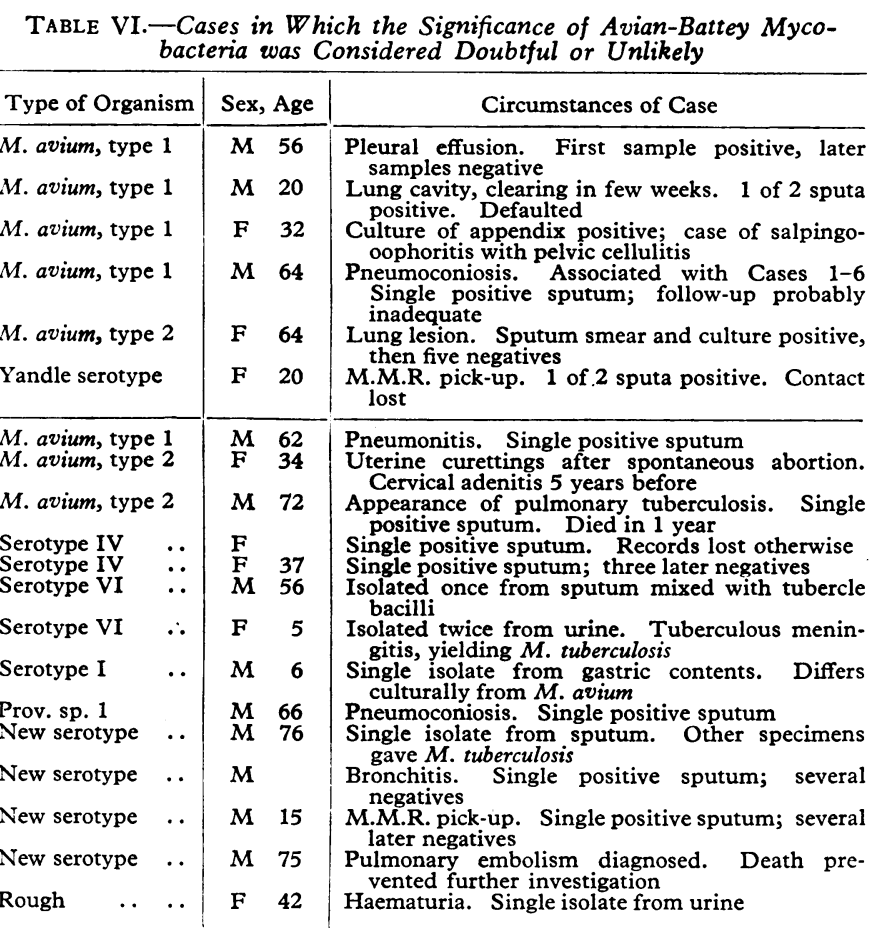

Significance of the mycobacteria was considered doubtful in the first six cases and unlikely in the remainder.

Although the numbers are too small for firm conclusions, the distribution of avian-Battey infections is consistent with a mainly rural incidence of $M$. avium and a more general incidence of the other members of the group. Birds, both wild and domestic, are the natural host of M. avium. Tuberculosis in poultry is decreasing, but there has been a relative increase at least of $M$. avium infections in cattle (Lesslie and Birn, 1967) and in pigs (Lesslie et al., 1968) as compared with $M$. bovis. The relative incidence of the three types of $M$. avium differs in birds and mammals, suggesting that their infectivity for the latter varies. Types 1 and 3 have the higher temperature range in vitro and may be less suited than type 2 to the lower temperature of mammals ; they also appear to lose more readily their natural virulence for fowls after a prolonged residence in man. In contrast, all $M$. avium strains types 1 and 3 isolated from birds and tested were lethal to fowls. The wider distribution of the Battey serotypes is consistent with a normally free-living existence. Rather similar organisms have been found in soil, but the problem of their habitat has not yet been adequately studied.

The drugs developed for treating tuberculosis are mostly illsuited to avian-Battey mycobacteria, and it is not clear whether the patients who recovered had benefited from chemotherapy. The prognosis is especially grave when pneumoconiotics become infected, as was recognized by Kamat et al. (1961). When men in dusty occupations are excluded, the incidence of pulmonary and non-pulmonary infections is about equal. The latter are mostly cases of cervical adenitis which have a favourable course, though excision is sometimes considered necessary.

The problems of avian-Battey infection reflect those of opportunist mycobacteria in general. We know little of their epidemiology at present and we need more effective chemotherapy. The increasing extent of the problem demands greater activity in both these fields. Finally, the recession of tuberculosis has important immunological consequences which need to be studied.

We are indebted to Dr. W. J. Greene for help in the Rhondda investigation and to many physicians and bacteriologists for their co-operation in this study. One of us (W. B.S.) was partially supported by a U.S. Public Health Service Grant No. AI 04344.

Requests for reprints should be sent to the Tuberculosis Reference Laboratory, 'The Parade, Cardiff.

\section{REFERENCES}

Birn, K. J., Schaefer, W. B., Jenkins, P. A., Szulga, T., and Marks, J. (1967). Fournal of Hygiene, 65, 575 .

Clark, J., Thomson, D. S., and Wallace, A. (1968). Tubercle, 49, 31.

Feldman, W. H. (1938). Avian Tuberculosis Infections. London, Baillière, Tindal and Cox.

Griffith, A. S. (1938). Proceedings of the Royal Society of Medicine, 31, 1208.

Kamat, S. R., Rossiter, C. E., and Gilson, J. C. (1961). Thorax, 16, 297.

Lesslie, I. W., and Birn, K. J. (1967). Veterinary Record, 80, 559.

Lesslie, I. W., Birn, K. J., Stuart, P., O’Neill, P. A. F., and Smith, J. (1968). Veterinary Record, 83, 647.

Marks, J., and Birn, K. J. (1963). British Medical fournal, 2, 1503.

Schaefer, W. B. (1965). American Review of Respiratory Diseases, 92, p. 85.

Schonell, M. E., Crofton, J. W., Stuart, A. E., and Wallace, A. (1968). 